\title{
Brain-Derived Neurotrophic Factor Differentially Regulates Excitatory and Inhibitory Synaptic Transmission in Hippocampal Cultures
}

\author{
M. McLean Bolton, Andrew J. Pittman, and Donald C. Lo \\ Department of Neurobiology, Duke University Medical Center, Durham, North Carolina 27710
}

\begin{abstract}
Brain-derived neurotrophic factor (BDNF) has been postulated to be a key signaling molecule in regulating synaptic strength and overall circuit activity. In this context, we have found that BDNF dramatically increases the frequency of spontaneously initiated action potentials in hippocampal neurons in dissociated culture. Using analysis of unitary synaptic transmission and immunocytochemical methods, we determined that chronic treatment with BDNF potentiates both excitatory and inhibitory transmission, but that it does so via different mechanisms. BDNF strengthens excitation primarily by augmenting the amplitude of AMPA receptor-mediated miniature EPSCs (mEPSCs) but enhances inhibition by increasing the frequency of mIPSC and increasing the size of GABAergic synaptic terminals. In contrast to observations in other systems, BDNF-
\end{abstract}

Members of the neurotrophin family of peptide growth factors, particularly brain-derived neurotrophic factor (BDNF), are emerging as important mediators of activity-dependent modifications in synaptic strength. Their biological roles in such processes, however, remain uncertain. Whereas in some situations BDNF has been found to increase synaptic strength, such as at developing neuromuscular synapses and at excitatory synapses onto CA1 hippocampal neurons (Lohof et al., 1993; Vicario-Abejon et al., 1998; Sherwood and Lo, 1999), in cortical cultures, BDNF has been proposed to regulate the strength of all synapses onto a given neuron to maintain homeostasis (Rutherford et al., 1998). Consistent with both of these potential biological roles, the production and release of BDNF is activity-dependent in a variety of neuronal systems (McAllister et al., 1999).

Evidence supporting a role for BDNF in activity-dependent strengthening of specific synapses falls into two categories: acute experiments in which the effects of BDNF manifest within minutes, and chronic experiments in which effects take days to develop. Suppression of BDNF expression by gene deletion or introduction of antisense oligonucleotides results in deficiencies in hippocampal long-term potentiation (LTP), which can be rescued by acute provision of exogenous BDNF (Korte et al., 1995,

Received Nov. 10, 1999; revised Jan. 21, 2000; accepted Feb. 2, 2000.

This work was supported by National Institutes of Health Grants NS32742 (to D.L.) and MH11519 (to M.B.) and The McKnight Endowment Fund for Neuroscience (D.L.). We thank D. Fitzpatrick, S. Lesser, N. Tang Sherwood, and T. Yacoubian for their helpful comments on this manuscript and valuable discussions on experimental design. We also thank Regeneron Pharmaceuticals for their generous provision of recombinant BDNF and TrkB-IgG.

Correspondence should be addressed to Donald C. Lo, Department of Neurobiology Box 3209, Duke University Medical Center, Durham, NC 27710. E-mail: lo@neuro.duke.edu.

Copyright (C) 2000 Society for Neuroscience $\quad 0270-6474 / 00 / 203221-12 \$ 15.00 / 0$ mediated increases in AMPA-receptor mediated mEPSC amplitudes did not require activity, because blocking action potentials with tetrodotoxin for the entire duration of BDNF treatment had no effect on the magnitude of this enhancement. These forms of synaptic regulations appear to be a selective action of BDNF because intrinsic excitability, synapse number, and neuronal survival are not affected in these cultures. Thus, although BDNF induces a net increase in overall circuit activity, this results from potentiation of both excitatory and inhibitory synaptic drive through distinct and selective physiological mechanisms.

Key words: neurotrophins; BDNF; hippocampal neurons; synaptic plasticity; excitatory synaptic transmission; inhibitory synaptic transmission; AMPA receptors; NMDA receptors

1996a,b; Patterson et al., 1996). BDNF has also been reported to enhance basal synaptic transmission at Schaffer collateral-CA1 synapses (Kang and Schuman, 1995a,b) (but see Figurov et al., 1996; Patterson et al., 1996; Frerking et al., 1998; Gottschalk et al., 1998) and to interact with tetanus-induced LTP in this region (Figurov et al., 1996; Gottschalk et al., 1998; Korte et al., 1998). Similar acute potentiative effects have been found in the hippocampal CA3 region and dentate gyrus (Scharfman, 1997, 1999). In neocortex, there is evidence that BDNF potentiates basal synaptic transmission (Akaneya et al., 1996, 1997; Carmignoto et al., 1997) (but see Huber et al., 1998; Kinoshita et al., 1999) and that BDNF increases the probability of inducing LTP rather than long-term depression for a range of stimulus paradigms (Akaneya et al., 1996, 1997; Huber et al., 1998; Kinoshita et al., 1999; Sermasi et al., 1999). Finally, rapid enhancement of excitatory transmission has also been demonstrated in dissociated hippocampal cultures (Lessmann et al., 1994; Levine et al., 1995, 1996, 1998; Lessmann and Heumann, 1998; Li et al., 1998; Song et al., 1998) and at developing neuromuscular synapses in culture (Lohof et al., 1993; Wang et al., 1995; Stoop and Poo, 1996; Boulanger and Poo, 1999a,b).

More recently, long-term synaptic strengthening by BDNF has been observed in cultured hippocampal neurons. In autaptic cultures of glutamatergic CA1 neurons, chronic BDNF treatment increases quantal amplitude and the amplitude of evoked synaptic transmission in parallel (Sherwood and Lo, 1999). In dissociated cultures of early embryonic hippocampal neurons, BDNF increases the number of functional synaptic connections (VicarioAbejon et al., 1998). In contrast, studies of long-term effects of BDNF in dissociated cortical cultures have suggested that BDNF decreases neuronal firing rate by reducing the strength of all excitatory inputs onto a given neuron (Rutherford et al., 1998; 
Turrigiano and Nelson, 1998; Turrigiano et al., 1998; Turrigiano, 1999).

To begin to understand this apparent pleiotropy of BDNF action, we examined the regulation of synaptic activity by BDNF in hippocampal cultures in which effects on overall action potential activity, excitation, and inhibition can be analyzed separately. In these cultures, we observed that, rather than maintaining action potential firing rates at a constant level, BDNF increased overall spontaneous firing rate by approximately threefold. We found that actions of BDNF underlying this increase in activity involved enhancement of both excitatory and inhibitory synaptic transmission in parallel but via distinct cellular mechanisms. BDNF selectively increased the quantal amplitude of AMPA receptor-mediated excitatory transmission, an increase that did not require ongoing action potential activity. In contrast, BDNF did not affect the quantal amplitude of GABAergic transmission but rather increased the frequency of spontaneous quantal inhibitory transmission. Thus, although these effects contained a homeostatic component, the overall action of BDNF was strongly stimulatory and supports a role for BDNF as a mediator of activity-dependent plasticity in vivo.

\section{MATERIALS AND METHODS}

Cell culture. Standard dissociated hippocampal cultures were prepared from postnatal day 0 rat pups using the technique of Pan et al. (1993). Briefly, rat pups were anesthetized using isofluorane, and hippocampi were dissected into HBSS (Life Technologies, Gaithersburg, MD) with $10 \mathrm{~mm}$ HEPES. Each hippocampus was diced and incubated at $37^{\circ} \mathrm{C}$ for $45 \mathrm{~min}$ in HBSS containing $20 \mathrm{U} / \mathrm{ml}$ papain (Worthington, Freehold, NJ), $0.5 \mathrm{~mm}$ EDTA, $1.5 \mathrm{~mm} \mathrm{CaCl}_{2}$, and $10 \mathrm{~mm}$ HEPES (Sigma, St. Louis, $\mathrm{MO})$. The papain solution was removed, and residual papain was inactivated by the addition of serum-containing medium. The cells were then triturated by passage through fire-polished Pasteur pipettes with sequentially smaller diameter openings. Cells were plated at a density of 200,000 cells per dish in $35 \mathrm{~mm}$ dishes that had been coated with poly-D-lysine and merosin (Life Technologies). After $1 \mathrm{~d}$ in culture, $25 \%$ of the medium was exchanged, and the mitotic inhibitor 5-fluoro-2-deoxyuridine was added to minimize glial proliferation.

Neurotrophin treatment. Hippocampal cultures were allowed to establish for $3 \mathrm{~d}$, after which either $100 \mathrm{ng} / \mathrm{ml} \mathrm{BDNF}$ or $5 \mu \mathrm{g} / \mathrm{ml}$ TrkB-IgG (both generous gifts from Regeneron Pharmaceuticals, Tarrytown, NY) was added; we have shown previously that these concentrations of BDNF and TrkB-IgG are effective over the time course of several days and are low enough to avoid cross activation of other neurotrophin receptors (Lesser and Lo, 1995; Lesser et al., 1997; Riddle et al., 1997; Sherwood et al., 1997; Sherwood and Lo, 1999). Electrophysiological recordings were made after 4-7 d of treatment.

Electrophysiology. Electrophysiological recordings were made with an Axopatch 1D patch-clamp amplifier (Axon Instruments, Foster City, CA), and data were acquired using an INDEC Systems analog-to-digital converter and custom software written in-house in Visual Basic (Microsoft, Seattle, WA). Whole-cell patch-clamp recording was done using standard methods (Hamill et al., 1981). Borosilicate patch pipettes were pulled to resistances of 3-4 M $\Omega$. For synaptic currents, data were acquired continuously at $2.5 \mathrm{kHz}$ sampling frequency and filtered at 1 $\mathrm{kHz}$ using a four-pole Bessel filter. Recordings with leak currents $>100$ pA or series resistances $>20 \mathrm{M} \Omega$ were discarded.

For recording AMPA receptor-mediated synaptic currents, the extracellular solution contained (in mM): $137 \mathrm{NaCl}, 5 \mathrm{KCl}, 3 \mathrm{CaCl}_{2}, 1 \mathrm{MgCl}_{2}$, 10 glucose, and 5 HEPES, adjusted to $310 \mathrm{mOsm}$ and $\mathrm{pH}$ 7.25. To block $\mathrm{GABA}_{\mathrm{A}}$ receptor-mediated and action potential-driven synaptic transmission, $25 \mu \mathrm{M}$ bicuculline and $1 \mu \mathrm{M}$ tetrodotoxin (TTX) were included in the extracellular solution. The intracellular solution contained (in mM): 100 gluconic acid, 0.6 EGTA, $5 \mathrm{MgCl}_{2}, 2 \mathrm{Na}_{2}$-ATP, $0.3 \mathrm{Na}_{2}$-GTP, and $40 \mathrm{HEPES}$, adjusted to $310 \mathrm{mOsm}$ and $\mathrm{pH} \mathrm{7.25}$. For recording NMDA receptor-mediated synaptic currents, identical solutions were used, except that the extracellular solution was nominally $\mathrm{Mg}^{2+}$-free and contained $3 \mu \mathrm{M}$ 2,3-dihydroxy-6-nitro-7-sulphamoylbenzo(f)-quinoxalinedione (NBQX) and $10 \mu \mathrm{M}$ glycine. For recording $\mathrm{GABA}_{\mathrm{A}}$ receptormediated synaptic currents, the intracellular solution contained (in $\mathrm{mM}$ ):
$110 \mathrm{KCl}, 10$ EGTA, $5 \mathrm{MgCl}_{2}, 2 \mathrm{Na}_{2}$-ATP, $0.3 \mathrm{Na}_{2}$-GTP, and $30 \mathrm{HEPES}$, adjusted to $310 \mathrm{mOsm}$ and $\mathrm{pH} 7.25$. The extracellular solution was the same as described for AMPA receptor-mediated currents but containing $3 \mu \mathrm{M}$ NBQX instead of bicuculline.

Intrinsic excitability was measured in current-clamp mode. The intracellular solution contained (in $\mathrm{mM}$ ): $144 \mathrm{~K}$-gluconate, 0.5 EGTA, 1 $\mathrm{MgCl}_{2}, 2 \mathrm{Na}_{2} \mathrm{ATP}, 0.3 \mathrm{Na}_{2} \mathrm{GTP}$, and $0.5 \mathrm{HEPES}$, adjusted to $310 \mathrm{mOsm}$ and $\mathrm{pH} 7.25$. Membrane voltages were sampled at $10 \mathrm{kHz}$ and filtered at $2 \mathrm{kHz}$. To elicit action potential activity, a series of depolarizing pulses of $160 \mathrm{msec}$ duration were delivered to the cells. Input-output relationships were determined by plotting the current injected versus action potential firing frequency. Action potential height, half-width, and spike threshold were measured off-line. Membrane capacitance, series resistance, and input resistance were measured under voltage clamp.

On-cell patch-clamp recording was used for noninvasive measurement of the frequency of action potential activity. Data were acquired at $5 \mathrm{kHz}$ in voltage-follower recording mode and filtered at $2 \mathrm{kHz}$. The extracellular and pipette solutions were the same, containing (in $\mathrm{mm}$ ): $137 \mathrm{NaCl}$, $5 \mathrm{KCl}, 3 \mathrm{CaCl}_{2}, 1 \mathrm{MgCl}_{2}, 10$ glucose, 0.01 glycine, and $5 \mathrm{HEPES}$, adjusted to $310 \mathrm{mOsm}$ and $\mathrm{pH} 7.25$.

Immunocytochemistry. To measure neuronal survival and the percentage of inhibitory neurons, parallel cultures were double-labeled using a mouse monoclonal antibody directed against the GABAergic neuronal marker glutamic acid decarboxylase (GAD) (1:500; Chemicon, Temecula, CA) and a rabbit polyclonal antibody against neuron-specific enolase (NSE) (1:500; Chemicon). GAD immunostaining was visualized with an Oregon Green 488-conjugated goat anti-mouse secondary antibody (1:400; Molecular Probes, Eugene, OR); NSE immunostaining was visualized with a $\mathrm{Cy} 3$-conjugated goat anti-rabbit secondary antibody (1:400; Chemicon). On the fifth day of neurotrophin treatment, cultures were fixed in $4 \%$ paraformaldehyde and 5\% sucrose in PBS and then washed with PBS. Nonspecific binding was blocked with $10 \%$ goat serum in PBS, and cells were permeabilized with $0.1 \%$ Triton X-100. Cultures were then incubated overnight with primary antibody at $4^{\circ} \mathrm{C}$, followed by incubation in secondary antibody for $1 \mathrm{hr}$ at room temperature. Finally, cultures were rinsed with PBS, mounted in Molwiol, and coverslipped.

Cell counts were done with the experimenter blinded on an inverted Zeiss (Oberkochen, Germany) microscope (Axiovert) with a $10 \times$ objective. Mean numbers of GAD- or NSE-positive neurons per field were calculated by counting the number of GAD-positive cells in a field using fluorescein filters and then switching to rhodamine filters and recounting the same field for NSE-positive cells. Fields were analyzed by randomly placing the objective and then sequentially moving the dish through a vertical strip of 10 fields.

To quantify total numbers of synapses per field and numbers of inhibitory synapses per field, cultures were double-labeled using a mouse anti-synapsin monoclonal antibody (1:500; Chemicon) and a rabbit antiGAD polyclonal antibody (1:1000; Chemicon). GAD immunostaining was visualized with an Oregon Green 488-conjugated goat anti-rabbit secondary antibody (1:500; Molecular Probes); synapsin immunostaining was visualized with a Cy3-conjugated goat anti-mouse secondary antibody (1:500; Chemicon). The immunostaining procedure was the same as described above.

As for cell counts, synapse quantification was done with the experimenter blinded. Images were acquired and digitized using a Hamamatsu (Shizouka, Japan) chilled CCD camera on a Zeiss Axioscope using a $40 \times$ oil-immersion objective; exposure times were held constant for each fluorochrome. Images were taken by randomly placing the objective and then sequentially moving the dish through a vertical strip of 10 fields. Images were analyzed using Scion Image software (Scion Corp., Frederick, MD); briefly, a mask containing the location and area of each synapsin or GAD puncta was made using a combination of thresholding and manual highlighting. Numbers, areas, and intensities of these punctae were then determined using built-in Scion Image functions.

\section{RESULTS}

\section{BDNF increases spontaneous activity in dissociated cultures of hippocampal neurons}

To investigate the role of BDNF in regulating the overall excitability of dissociated cultures of hippocampal neurons, cultures were treated for 4-7 d with $100 \mathrm{ng} / \mathrm{ml}$ BDNF and compared with untreated controls and cultures in which endogenous BDNF was neutralized with $5 \mu \mathrm{g} / \mathrm{ml}$ TrkB-IgG (Shelton et al., 1995; McAl- 
$\mathbf{A}$

B
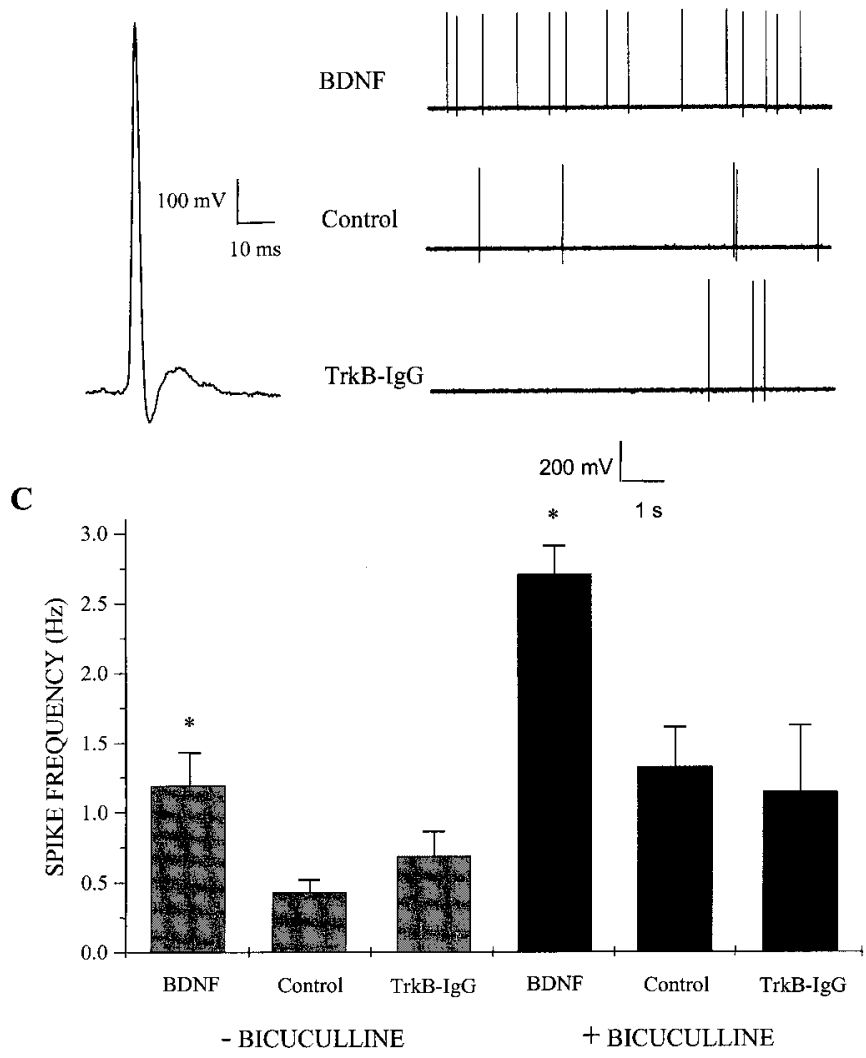

Figure 1. BDNF increases spontaneous action potential firing rate. $A$, Representative trace illustrating the waveform of an action potential recorded with an on-cell patch pipette; this configuration was used to measure action potential frequency in dissociated hippocampal cultures. Voltage traces were inverted about the vertical axis to conform to convention. Data were acquired at $5 \mathrm{kHz}$ in voltage-follower recording mode and filtered at $2 \mathrm{kHz}$. B, Spontaneous action potential firing was increased in cultures treated with BDNF. Representative on-cell recordings shown at a compressed time base from cells treated for $4-7 \mathrm{~d}$ with $100 \mathrm{ng} / \mathrm{ml}$ BDNF (top), untreated (Control, middle), or treated with $5 \mu \mathrm{g} / \mathrm{ml}$ TrkBIgG (bottom). Cultures were rinsed in recording saline several times to ensure that no BDNF or TrkB-IgG was present at the time of recording. $C$, Left, BDNF treatment increased the spontaneous firing rate of pyramidal neurons approximately threefold compared with untreated controls; means \pm SEM are shown. ${ }^{*} p<0.009$ indicates a significant difference by ANOVA between BDNF and either control or TrkB-IgG treatment groups; $n=33,27$, and 36 for BDNF, control, and TrkB-IgG groups, respectively. Right, Elevated action potential firing rates induced by BDNF persisted in disinhibited circuits. BDNF appeared to increase excitatory synaptic transmission directly because the increase in spontaneous firing rates of pyramidal neurons persisted after acute blockade of inhibitory transmission by bicuculline during the recording period. ${ }^{*} p<$ $3 \times 10^{-5}$ indicates a significant difference by ANOVA between BDNF and either control or TrkB-IgG treatment groups; $n=43,36$, and 12 for BDNF, control, and TrkB-IgG groups, respectively.

lister et al., 1996, 1997). Spontaneous action potentials in neurons with pyramidal morphology were then recorded using cellattached patch-clamp recording as a rapid and relatively noninvasive measurement of circuit activity. BDNF treatment increased the average spontaneous action potential firing rates of neurons by approximately threefold compared with untreated controls $(n=33,27$, and 36 for BDNF, control, and TrkB-IgG cultures, respectively; BDNF vs control, $p<0.009$ by ANOVA) (Fig. 1). Interestingly, there was no significant difference between untreated controls and TrkB-IgG-treated neurons with respect to firing rate $(p>0.60)$ or for any other electrophysiological parameter measured in this study, suggesting that levels of endogenous BDNF are below the physiological threshold required to modulate activity in these low-density cultures. This is consistent with the finding that endogenous BDNF levels are negligible in autaptic hippocampal cultures (Sherwood and Lo, 1999).

This striking increase in spontaneous firing rate could have arisen from an increase in the strength of excitation, a decrease in the strength of inhibition, or both. To evaluate the effect of BDNF on excitation directly, the contribution of inhibition to circuit activity was eliminated during the period of electrophysiological recording by pharmacologically blocking $\mathrm{GABA}_{\mathrm{A}}$ receptors acutely with bicuculline and measuring action potential firing rates in these disinhibited circuits. Under these conditions, BDNF still elevated spontaneous action potential firing rate by approximately twofold, indicating that the action of BDNF must include, at least in part, a direct potentiation of excitatory synaptic transmission ( $n=43,36$, and 12 for BDNF, control, and TrkB-IgG cultures, respectively; BDNF vs control, $p<3 \times 10^{-5}$ by ANOVA) (Fig. 1).

\section{BDNF does not influence neuronal survival}

We next asked whether the action of BDNF contained a component that influenced the balance of excitation and inhibition in these cultures via differential regulation of survival of excitatory versus inhibitory neurons. We found that, by quantifying neuronal density in BDNF-treated, control, and TrkB-IgG-treated cultures, BDNF had no measurable effect on total neuronal survival ( $n=161$ fields counted for each condition; $p>0.35$ by ANOVA for any pairwise comparison) (Fig. 2A). Although there was no change in overall neuronal density, BDNF increased the percentage of neurons expressing the inhibitory neuronal marker GAD ( $n=180$ fields counted for each condition; BDNF vs control, $p<$ 0.008 by ANOVA) (Fig. $2 B$ ).

There are two possible interpretations of this result. First, BDNF may have caused a decrease in the survival of nonGABAergic neurons that was exactly balanced by an increase in survival of GABAergic neurons. Second, BDNF may have promoted the neurochemical maturation of inhibitory neurons such that the level of GAD expression was increased to detectable levels in a greater percentage of inhibitory neurons, with no effect on neuronal survival per se. The latter interpretation is consistent with previous work suggesting that BDNF potentiates phenotypic differentiation of GABAergic neurons (Ip et al., 1993; Nawa et al., 1993; Mizuno et al., 1994; Ventimiglia et al., 1995; Marty et al., 1996a,b; Rutherford et al., 1997; Vicario-Abejon et al., 1998). Furthermore, other studies have shown that BDNF-mediated increases in GABA and neuropeptide expression levels are reversible, thus arguing against differential survival as a mechanism for BDNF action (Marty and Onteniente, 1997; Rutherford et al., 1997).

Because BDNF did not affect overall neuronal density and its enhancement of inhibitory neuronal differentiation would be predicted to decrease circuit activity, these factors were not likely to contribute positively to the observed increase of circuit activity induced by BDNF. Thus, these findings suggested that BDNF must increase circuit activity by other mechanisms, such as enhanced synaptic drive or by increased intrinsic membrane excitability.

\section{BDNF does not regulate intrinsic excitability}

Because the action potential firing properties of a network depend on the intrinsic excitability of its neuronal elements as well 
Figure 2. BDNF enhances the phenotypic differentiation of GABAergic neurons but has no effect on neuronal survival. Hippocampal cultures were treated for $5 \mathrm{~d}$ with either BDNF or TrkB-IgG or were left untreated; cultures were then double-labeled for the neuronal marker NSE and the GABAergic neuronal marker GAD. Numbers of NSE-positive and GAD-positive neurons were counted independently; all counts were done blind. $A$, BDNF treatment did not affect neuronal survival. Means \pm SEM are shown; $n=9$ dishes per condition with 20 fields counted and averaged per dish; $p>0.35$ for any pairwise comparison by ANOVA. $B$, BDNF increased the percentage of GAD-positive neurons. ${ }^{*} p<0.008$ indicates a significant difference by ANOVA between BDNF and either control or TrkBIgG treatment groups; $n=9$ dishes per condition with 20 fields counted and averaged per dish.
A

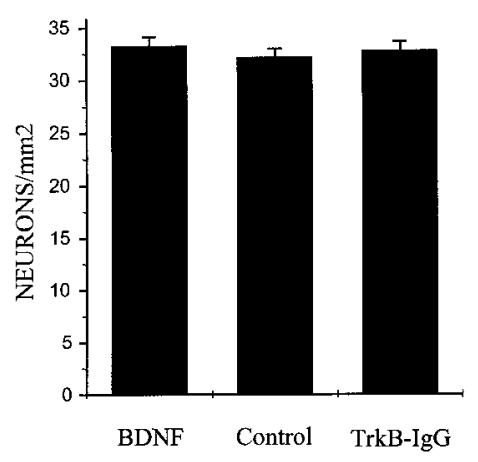

A

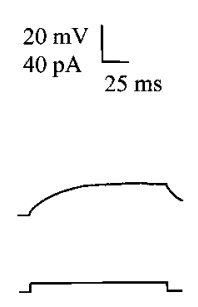

B

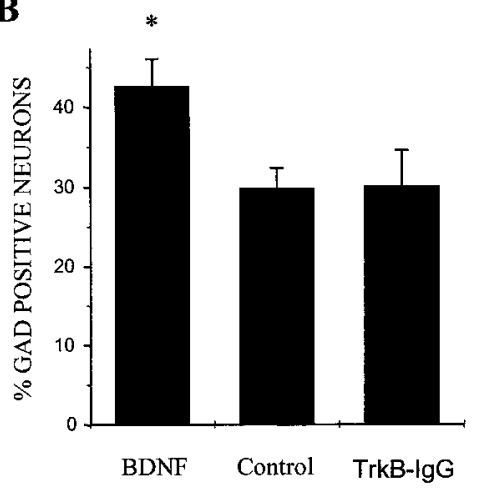

B

Figure 3. BDNF does not affect intrinsic membrane excitability. $A$, Representative whole-cell current-clamp traces of action potential trains elicited in a control cell by depolarizing the membrane by a sequence of inward current pulses (left to right: 10,20,30, and $40 \mathrm{pA}$ ). Top traces show voltage responses to $160 \mathrm{msec}$ depolarizing current pulses (bottom traces) relative to resting potential; synaptic transmission was blocked pharmacologically during the recording period as described in Materials and Methods. Data were sampled at $10 \mathrm{kHz}$ and filtered at $2 \mathrm{kHz} . B, \mathrm{BDNF}$ treatment did not alter input-output relationships for current injection versus action potential firing rate. Neither augmentation (squares) nor depletion (circles) of BDNF affected action potential firing rate at any of the current injection amplitudes examined compared with untreated controls (triangles). Means \pm SEM are shown; $n=27,23$, and 24 for BDNF, control, and TrkB-IgG groups, respectively.

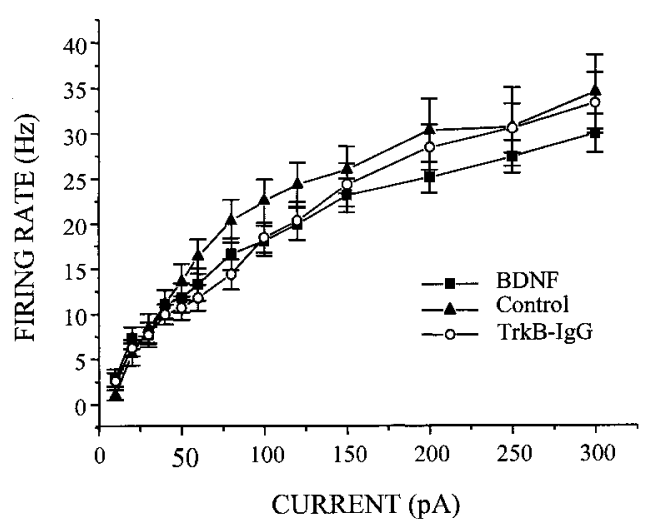

as the synaptic connectivity of the ensemble, we next investigated whether BDNF regulated intrinsic membrane excitability in these cultures. Accordingly, we measured several parameters of action potential activity that was generated by injecting a series of current pulses of increasing amplitude into current-clamped neurons; voltage responses to these current pulses were measured while all synaptic transmission was blocked pharmacologically. Most importantly, we found that BDNF did not change the firing rate of neurons at any of the current injection amplitudes examined (Fig. 3). Additionally, we found that BDNF affected neither action potential shape, as measured by action potential height and half-width (Table 1), nor the voltage threshold at which the regenerative action potentials were first observed.

Similarly, there were no differences between BDNF-treated and control or TrkB-IgG-treated neurons in resting membrane potential (Table 1), but BDNF did cause a small increase in

capacitance and a decrease in input resistance (Table 1). These minor differences in particular membrane properties suggested that BDNF may have had small effects on the morphology of these neurons, but it is unlikely that these differences contributed significantly to increasing spontaneous circuit activity for two reasons: first, neither the shape, frequency, or voltage-threshold of action potentials, nor any other aspect of intrinsic excitability measured, was changed by BDNF; second, the rise and decay kinetics of AMPA receptor-mediated synaptic currents were not affected by BDNF (see following sections).

\section{BDNF selectively increases the amplitude of AMPA receptor-mediated miniature EPSCs}

Because the firing rate of neurons is determined, in part, by the number, strength and temporal characteristics of its individual excitatory and inhibitory synaptic inputs, we next examined the 
Table 1. BDNF does not alter intrinsic excitability

\begin{tabular}{lccc} 
& \multicolumn{1}{l}{ BDNF } & Control & TrkB-IgG \\
\hline$V_{\mathrm{m}}(\mathrm{mV})$ & $-50.7 \pm 1.3, n=24$ & $-50.8 \pm 1.3, n=20$ & $-49.3 \pm 1.1, n=24$ \\
$R_{\text {in }}(\mathrm{M} \Omega)$ & $175.8 \pm 16.1, n=27$ & $213.4 \pm 16.9, n=22$ & $220.7 \pm 20.2, n=24$ \\
$C_{\mathrm{m}}(\mathrm{pF})$ & $69.1 \pm 3.6, n=27^{*}$ & $58.2 \pm 3.3, n=22$ & $55.5 \pm 2.8, n=24$ \\
$V_{\mathrm{T}}(\mathrm{mV})$ & $-35.1 \pm 1.0, n=24$ & $-33.0 \pm 1.2, n=20$ & $-33.3 \pm 0.9, n=24$ \\
AP $1 / 2$-width $(\mathrm{msec})$ & $2.1 \pm 0.2, n=24$ & $2.1 \pm 0.2, n=20$ & $1.8 \pm 0.2, n=24$ \\
AP height $(\mathrm{mV})$ & $93.2 \pm 3.05, n=24$ & $101.4 \pm 3.6, n=20$ & $96.7 \pm 2.8, n=24$
\end{tabular}

Neither long-term augmentation or depletion of BDNF affected the shape of action potentials or the voltage threshold for action potential initiation ( $V_{\mathrm{m}}$, resting potential; $R_{\mathrm{in}}$, input resistance; $C_{\mathrm{m}}$, membrane capacitance; $V_{\mathrm{T}}$, voltage threshold for action potential initiation; AP 1/2-width, width of action potential at half-height; AP height, height of action potential; procedures as described in Materials and Methods). A small increase in capacitance, however, suggested the possibility of minor morphological changes; asterisk denotes significant differences between BDNF and control groups $(p<0.03$ by ANOVA) and between BDNF and TrkB-IgG groups $(p<0.005$ by ANOVA) with respect to cell capacitance. No other differences were statistically significant at the 0.05 level by ANOVA for any parameter measured.

A

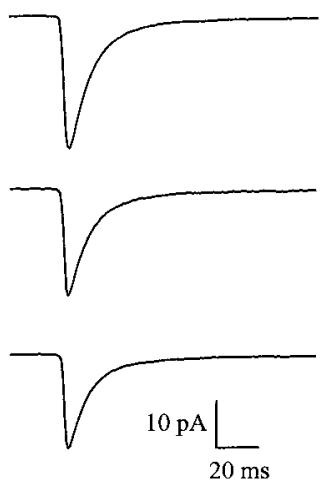

BDNF

B

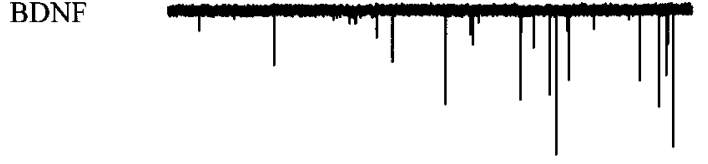

Control

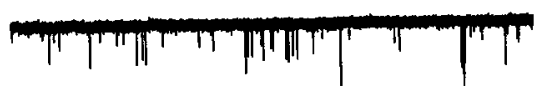

TrkB-IgG

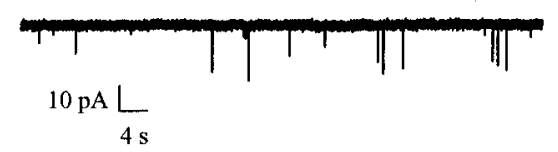

Figure 4. BDNF increases the amplitude but does not change the kinetics of AMPA receptor-mediated mEPSCs. $A$, Population averages of pharmacologically isolated AMPA receptor-mediated mEPSCs from all cells in each treatment group show the increase in mEPSC amplitude induced by BDNF; $n=82,44$, and 69 for BDNF (top), control (middle), and TrkB-IgG (bottom) groups, respectively. Note that the time courses of these averaged mEPSCs are similar; data were acquired continuously under voltage clamp at 2.5 $\mathrm{kHz}$ and filtered at $1 \mathrm{kHz}$. $B$, Representative recordings of AMPA receptor-mediated mEPSCs on a compressed time base illustrate the lack of effect of BDNF treatment on mEPSC frequency; traces from neurons in BDNF (top), control (middle), and TrkB-IgG (bottom) groups are shown. effects of BDNF on unitary synaptic transmission. We first measured the behavior of miniature EPSCs (mEPSCs) by blocking sodium channel-mediated action potential activity with TTX and recording spontaneous $\mathrm{mEPSC}$ s under whole-cell voltage clamp (Fig. 4). We found that BDNF significantly increased the amplitude of AMPA receptor-mediated mEPSCs by $\sim 30 \%(n=82,44$, and 69 for BDNF, control, and TrkB-IgG cultures, respectively; BDNF vs control, $p<0.007$ by ANOVA) (Fig. 5A). BDNF shifted the cumulative probability distribution of AMPA receptor-mediated mEPSC amplitudes uniformly toward larger amplitudes (Fig. 5C), suggesting that the action of BDNF was not limited to a subset of synapses of a particular quantal size and that there was no saturation of mEPSC sizes at higher amplitudes. This increase in the amplitude of unitary synaptic transmission by BDNF was accompanied by a significant increase in mEPSC frequency in BDNF-treated compared with TrkB-IgG-treated cells, but not compared with control cells $(n=83,45$, and 73 for BDNF, control, and TrkB-IgG cultures, respectively; BDNF vs TrkB-IgG, $p<0.04$ by ANOVA; BDNF vs control, $p>0.7$ by ANOVA) (Fig. 5B). BDNF had no effect on the decay rates of either AMPA or NMDA receptor-mediated synaptic currents (Table 2). Together, these findings suggested that BDNF increased excitation in these cultures predominantly by selectively increasing the amplitude of AMPA receptor-mediated synaptic currents without substantially affecting other aspects of excitatory synaptic transmission.

\section{BDNF induction of AMPA receptor-mediated mEPSC amplitude does not require activity}

Several previous studies have reported that the actions of neurotrophins are activity-dependent or that activity and neurotro- phins interact in their regulation of the physiological properties of neurons and neuronal circuits (Marty et al., 1996a; McAllister et al., 1996; Rutherford et al., 1997). We therefore asked whether the potentiative effect of BDNF on excitation observed here was dependent on ongoing electrical activity by blocking action potential activity with $5 \mu \mathrm{M}$ TTX for the entire duration of BDNF or TrkB-IgG treatment. We found, surprisingly, that TTX had no effect on the enhancement of mEPSC amplitude by BDNF $(n=$ 38, 30, 39, and 29 for BDNF, TrkB-IgG, BDNF plus TTX, and TrkB-IgG plus TTX cultures, respectively; BDNF vs TrkB-IgG, $p<0.01$ by ANOVA; BDNF plus TTX vs TrkB-IgG plus TTX, $p<10^{-4}$ by ANOVA) (Fig. 6A). In fact, TTX appeared to increase slightly the magnitude of enhancement by BDNF, from 31 to $53 \%$ in the presence of TTX. We verified that the TTX used remained active for the duration of the experiment by applying media containing the TTX to naïve cells and observing complete sodium channel blockade (data not shown). Thus, the regulation of AMPA receptor-mediated mEPSC amplitude by BDNF did not require concurrent action potential activity and thus may differ from other reported actions of BDNF.

\section{BDNF selectively increases the frequency of GABA $_{A}$-mediated mIPSCs}

To determine whether BDNF also regulated the unitary properties of inhibitory synaptic transmission, we next recorded mIPSCs arising from GABAergic inputs onto neurons with pyramidal morphology. During the recording period, TTX and NBQX were added to the extracellular solution to block action potentials and glutamatergic inputs, respectively. We found that BDNF treatment increased the frequency of mIPSCs by almost twofold $(n=$ 35, 31, and 35 for BDNF, control, and TrkB-IgG cultures, respec- 
A

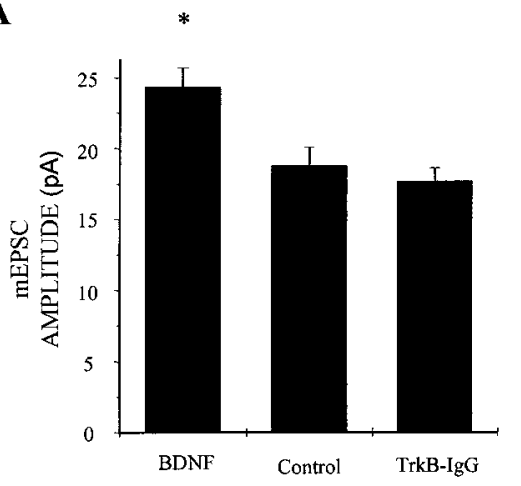

B

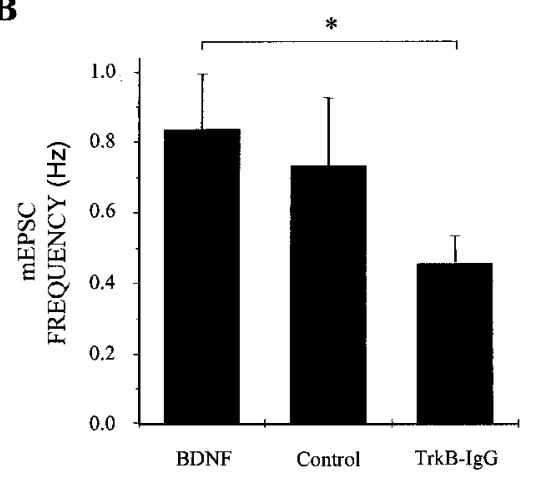

Figure 5. BDNF increases AMPA receptor-mediated mEPSC amplitude. $A$, BDNF increased mEPSC amplitude by $\sim 30 \%$ compared with control cells and by $\sim 40 \%$ compared with TrkB-IgG treated neurons $(n=$ 82,44 , and 69 for BDNF, control, and TrkB-IgG groups, respectively). ${ }^{*} p<0.007$ indicates a significant difference by ANOVA between BDNF and either control or TrkB-IgG groups; means \pm SEM are shown. Data were acquired continuously under voltage clamp at $2.5 \mathrm{kHz}$ and filtered at $1 \mathrm{kHz} . B, \operatorname{mEPSC}$ frequency was elevated by BDNF- compared with TrkB-IgGtreated cells but not significantly so compared with control cells; $n=83,45$, and 73 for BDNF, control, and TrkB-IgG groups, respectively. ${ }^{*} p<0.042$ and line indicate a significant difference by ANOVA between the BDNF and TrkB-IgG groups; $p>0.69$ by ANOVA between BDNF and control groups. $C$, BDNF treatment shifted mEPSC amplitudes uniformly toward higher amplitudes as shown in cumulative probability distributions; all mEPSCs recorded in a 3 min interval from 40 randomly chosen neurons in each treatment condition were grouped and analyzed.

Table 2. BDNF does not alter decay kinetics of either excitatory or inhibitory synaptic currents

\begin{tabular}{llll}
\multicolumn{1}{c}{ AMPA } & NMDA & GABA $_{\mathrm{A}}$ \\
\hline BDNF & $6.4 \pm 0.4, n=63$ & $76.6 \pm 9.2, n=13$ & $31.9 \pm 1.2, n=35$ \\
Control & $5.9 \pm 0.4, n=31$ & - & $29.8 \pm 1.1, n=31$ \\
TrkB-IgG & $5.8 \pm 0.3, n=65$ & $84.1 \pm 13, n=13$ & $33.5 \pm 1.4, n=33$
\end{tabular}

Neither long-term augmentation nor depletion of BDNF affected the mean decay time constants (in milliseconds) for AMPA receptor-mediated mEPSCs ("AMPA"), NMDA receptor-mediated mEPSCs ("NMDA"), or GABA ${ }_{\mathrm{A}}$ receptormediated mIPSCs ("GABA ${ }_{\mathrm{A}}$ "); isolation and recording of these synaptic currents as described in Materials and Methods. Single exponential decay time constants were derived by iterative minimization of least squares differences; this was done on "true minis" in the presence of TTX for AMPA receptor-mediated mEPSCs and GABA receptor-mediated mIPSCs but on all spontaneous NMDA receptor-mediated mEPSCs to enhance signal-to-noise.

tively; BDNF vs control, $p<0.028$ by ANOVA) (Fig. $7 D$ ). In contrast to the increase in AMPA receptor-mediated mEPSC amplitude described above, $\mathrm{GABA}_{\mathrm{A}}$ receptor-mediated mIPSC amplitudes were not affected by $\operatorname{BDNF}(n=35,31$, and 35 for BDNF, control, and TrkB-IgG cultures, respectively; BDNF vs control, $p>0.6$ by ANOVA) (Fig. $7 C$ ). As with AMPA- and NMDA-mediated synaptic currents, BDNF did not alter the kinetics of synaptic currents mediated by $\mathrm{GABA}_{\mathrm{A}}$ receptors (Table 2). These findings indicated that, although BDNF potentiated both excitatory and inhibitory synaptic transmission in these cultures, it did so through distinct physiological mechanisms.

BDNF does not change synapse number but enhances differentiation of GABAergic terminals

Finally, we asked whether BDNF regulated inhibition by regulating numbers of GABAergic inputs because we observed that

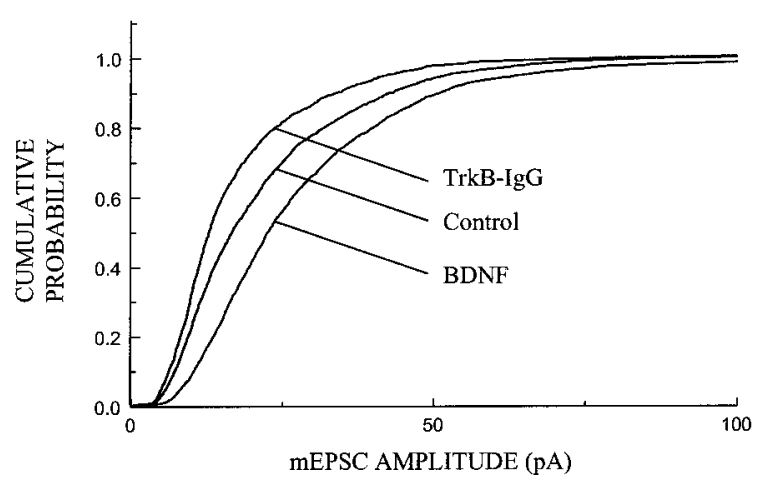

BDNF increased the frequency of mIPSCs. First, we quantified total numbers of presumptive synapses by immunostaining with antibodies against the synaptic vesicle protein synapsin I (Fig. $8 A$ ). Because synapsin $\mathrm{I}$ is present in the terminals of both excitatory and inhibitory neurons, these initial measurements reflected the combined number of glutamatergic and GABAergic synapses. BDNF did not increase numbers of synapses per field, terminal size, or intensity of synapsin labeling; in fact, there was a slight increase in numbers of synapses in cultures in which endogenous BDNF had been antagonized with TrkB-IgG (Fig. 9, left).

We next examined GABAergic terminals specifically with an antibody directed against GAD (Fig. 8B). BDNF did not increase the number of GAD-positive synapses; as found for synapsin staining, however, there was a slight increase in the number of GAD punctae with TrkB-IgG treatment (Fig. 9A, right). Strikingly, BDNF increased average GABA terminal size by $50 \%$ and concomitantly increased the fluorescence intensity of these punctae, presumably reflecting an increase in the level of GAD expression (Fig. 9B, right). Together with the increased mIPSC frequency described above, these observations suggest that BDNF increased inhibition by increasing the efficacy and/or probability of transmission at GABAergic synapses.

\section{DISCUSSION}

We have found that BDNF strongly regulates both excitation and inhibition in dissociated cultures of hippocampal neurons. Although the increase in excitation was dominant in that overall levels of spontaneous activity in these cultures were increased after BDNF treatment, this parallel enhancement of excitation and inhibition also resulted in partial homeostasis in terms of 
$\mathbf{A}$

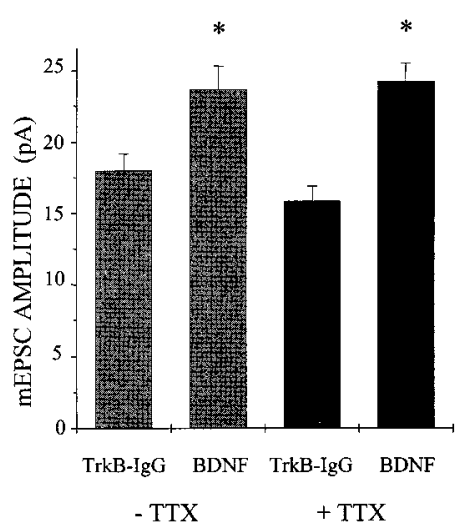

$\mathbf{A}$
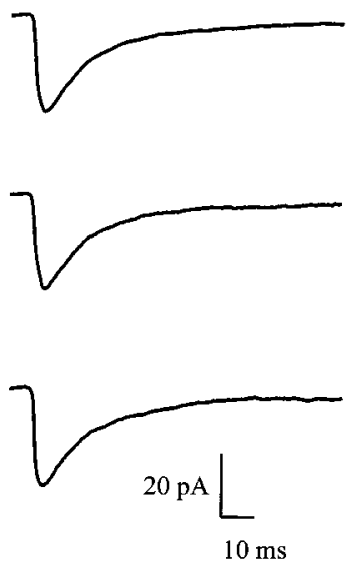

C

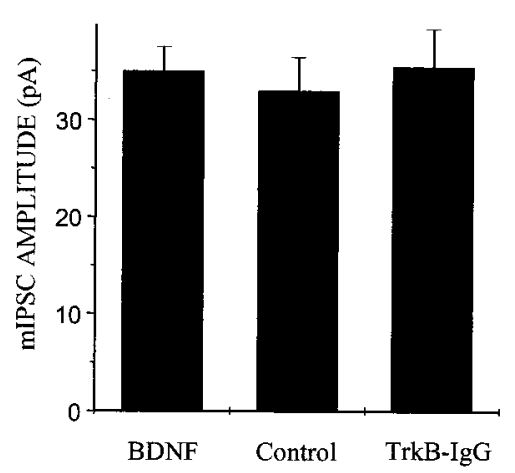

BDNF

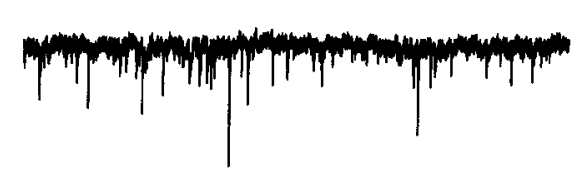

Control

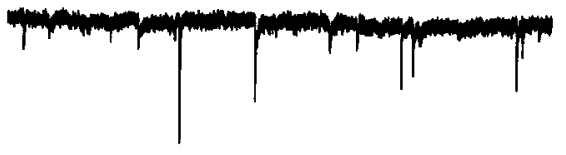

TrkB-IgG

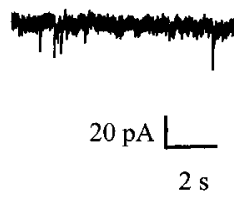

(2)

D

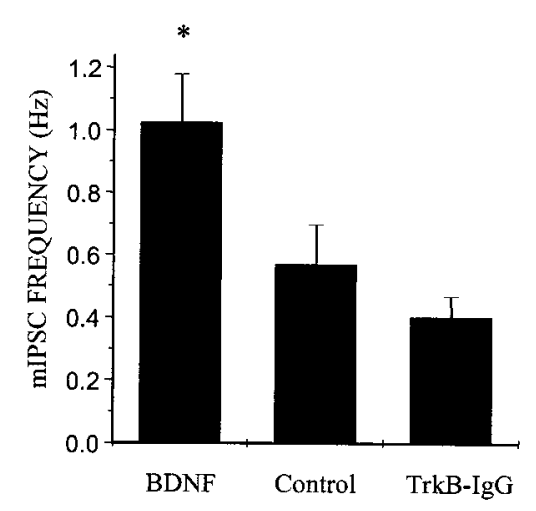

B

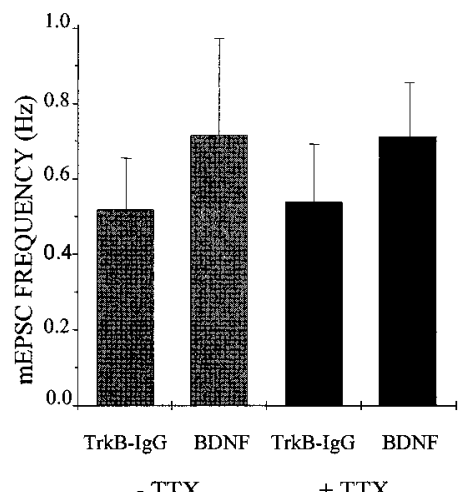

B

Figure 6. BDNF regulation of mEPSC amplitude does not require activity. $A$, The addition of $5 \mu \mathrm{M}$ TTX to block action potential activity for the entire duration of the treatment period did not block the enhancement of mEPSC amplitude by BDNF; mEPSC amplitudes increased by 31 and 53\% with and without TTX treatment, respectively. Means \pm SEM are shown; without TTX, $n=38$ and 30 for BDNF and TrkB-IgG groups, respectively, $p<0.01$ by ANOVA; with TTX, $n=39$ and 29 for BDNF and TrkB-IgG groups, respectively, $p<10^{-4}$ by ANOVA. $B$, BDNF, TTX, or BDNF and TTX treatment together did not significantly alter mEPSC frequency. Means \pm SEM are shown; without TTX, $n=38$ and 30 for BDNF and TrkB-IgG groups, respectively, $p>0.99$ by ANOVA; with TTX, $n=39$ and 29 for BDNF and TrkB-IgG groups, respectively, $p>0.93$ by ANOVA.

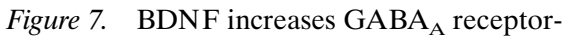
mediated mIPSC frequency but not amplitude. $A$, Population averages of pharmacologically isolated $\mathrm{GABA}_{\mathrm{A}}$ receptor-mediated mIPSCs from all cells in each treatment group show similar amplitude and time courses; $n=35,31$, and 33 for BDNF (top), control (middle), and TrkB-IgG (bottom) groups, respectively. Data were acquired continuously under voltage clamp at $2.5 \mathrm{kHz}$ and filtered at $1 \mathrm{kHz} . B$, Representative recordings of $\mathrm{GABA}_{\mathrm{A}}$ receptormediated mIPSCs on a compressed time base show the elevation of mIPSC frequency induced by BDNF treatment; traces from neurons in BDNF (top), control (middle), and TrkB-IgG (bottom) groups are shown. $C$, In contrast, BDNF treatment had no effect on $\mathrm{GABA}_{\mathrm{A}}$ receptor-mediated mIPSC amplitude. Means \pm SEM are shown; $n=35,31$, and 33 for BDNF, control, and TrkB-IgG groups, respectively. $D$, BDNF treatment increased mIPSC frequency by $\sim 1.8$ fold compared with controls. ${ }^{*} p<0.028$ indicates a significant difference by ANOVA between BDNF and either control or TrkB-IgG treatment groups; $n=35,31$, and 35 for BDNF, control, and TrkB-IgG groups, respectively. circuit activity. The increase in circuit activity produced by BDNF arose principally from changes in excitatory and inhibitory synaptic drive, both relative and absolute, but via distinct physiological mechanisms, with no significant changes in intrinsic neuronal excitability or neuronal survival.

\section{BDNF regulation of excitation}

We found that long-term treatment of hippocampal cultures with BDNF led to a selective increase in the quantal size of AMPA receptor-mediated mEPSCs. Such a change is consistent with a postsynaptic mechanism. Moreover, the absence of kinetic changes in AMPA receptor-mediated synaptic currents limits possible cellular and molecular mechanisms to those that do not alter the kinetic profile of postsynaptic currents. For example, an increase in numbers of functional AMPA receptors at synaptic sites would be expected to increase mEPSC amplitude without affecting kinetics; in fact, changes in the half-life of AMPA receptors can result in changes in receptor density that have been shown to correlate with quantal size (O'Brien et al., 1998). Recently, rapid insertion and removal of AMPA receptors from potentiated and depressed synapses has been proposed to under- 


\section{Synapsin}

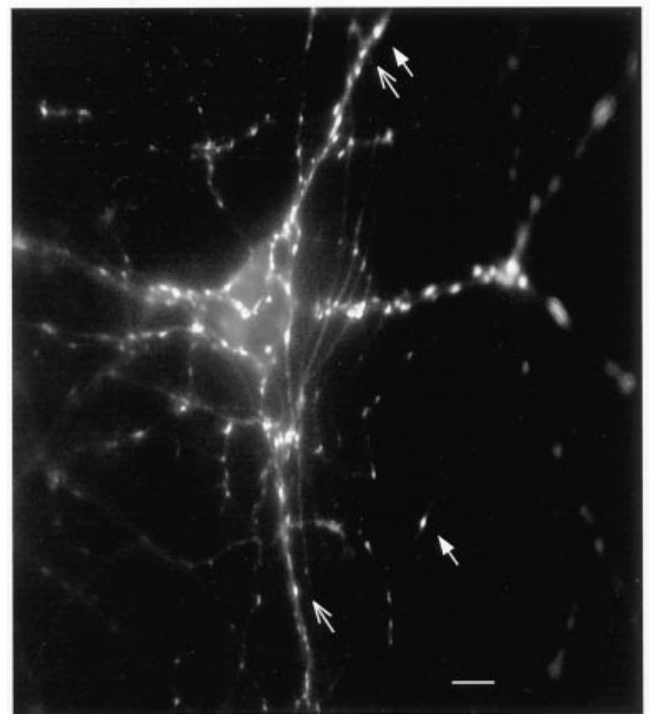

GAD

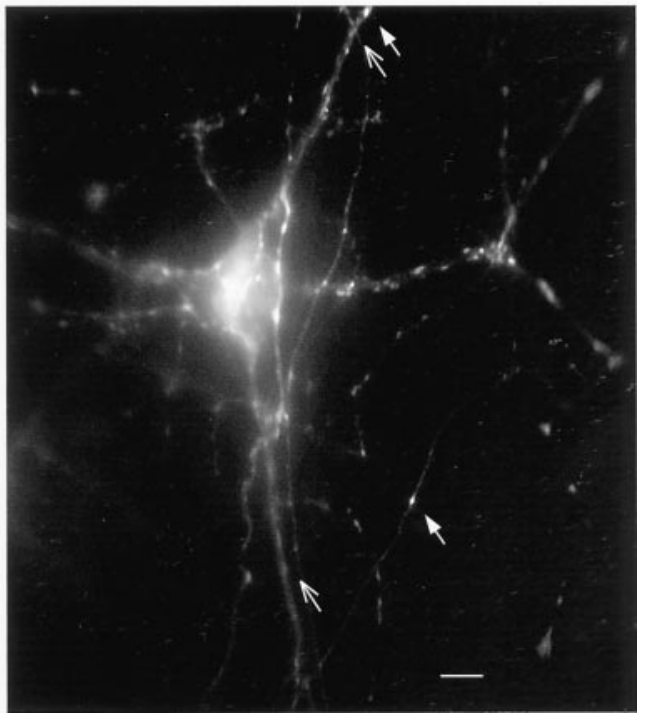

Figure 8. Immunostaining against synaptic markers in hippocampal neuronal cultures. Cultures were double-labeled with anti-synapsin and anti-GAD antibodies to visualize all and only GABAergic synaptic terminals, respectively. Synaptic punctae staining with both antibodies represented inhibitory presynaptic terminals (filled arrow), whereas those staining with the antisynapsin antibody only were considered to be excitatory (open arrow). Scale bar, $10 \mu \mathrm{m}$.

ever, our experiments do not specifically address mechanisms such as regulation of glutamate transporter function, whose contribution to synaptic current kinetics remains uncertain (for review, see Clements, 1996; Diamond and Jahr, 1997; Mennerick et al., 1999). Finally, that BDNF did not regulate the decay time course of NMDA receptor-mediated synaptic currents suggests that BDNF does not alter the subunit composition of the NMDA receptors under these conditions because changes in the relative expression of NR2A-NR2D subunits have been shown, for example, to alter NMDA receptor decay times significantly (Carmignoto and Vicini, 1992; Hestrin, 1992).

A previous study using hippocampal cultures from embryonic day 16 rats found similar BDNF-mediated increases in the amplitude of sucrose-evoked mEPSCs, but at this early developmental stage, the dominant effect was an increase in the number of functional synapses (Vicario-Abejon et al., 1998). Our results are more consistent with studies in CA1 hippocampal autapses in which BDNF induces a 1.7-fold increase in quantal amplitude of AMPA receptor-mediated mEPSCs and a parallel increase in the amplitude of evoked synaptic currents (Sherwood and Lo, 1999). Interestingly, the effects of BDNF described here and by VicarioAbejon et al. (1998) and Sherwood and Lo (1999) are quite different from those reported recently in dissociated cultures of visual cortical neurons (Rutherford et al., 1998; Turrigiano et al., 1998). In these studies, the quantal amplitude of AMPAmediated synaptic currents was scaled by activity; Rutherford et al. (1998) reported that BDNF prevents this increase in AMPA receptor-mediated quantal amplitude in response to activity blockade, the opposite of the action of BDNF found here. Interestingly, however, bipolar interneurons as described by Rutherford et al. (1998) responded to BDNF similarly to the hippocampal pyramidal neurons in the present study.

Such differences in BDNF regulation of synaptic transmission presumably arise from the pleiotropy and cell contextdependence of BDNF action and emphasize the diversity of roles BDNF may transpire to play in synaptic development and plasticity. In this context, it is notable that there are developmental

differences in the relative abundance of GluR1-GluR4 subunits crease induced by BDNF are limited to those that do not affect the rate of decay of synaptic currents, as discussed above; how- 


\section{Synapsin}

A

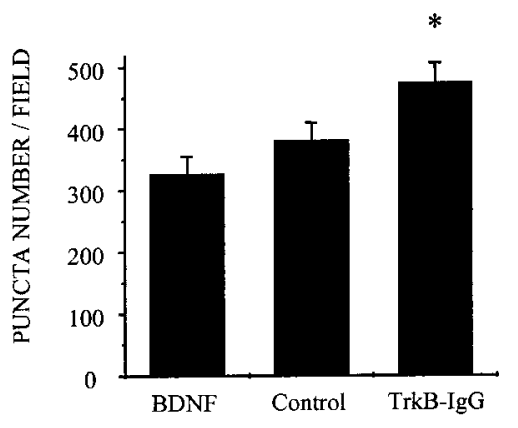

B

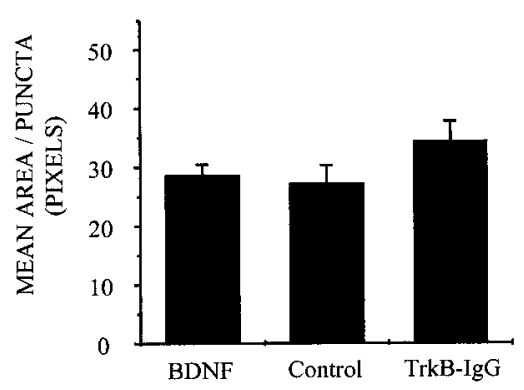

C

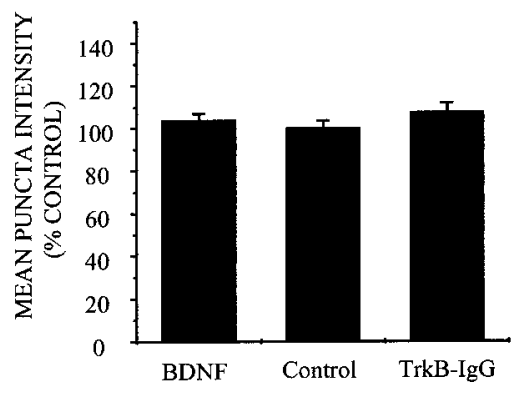

GAD
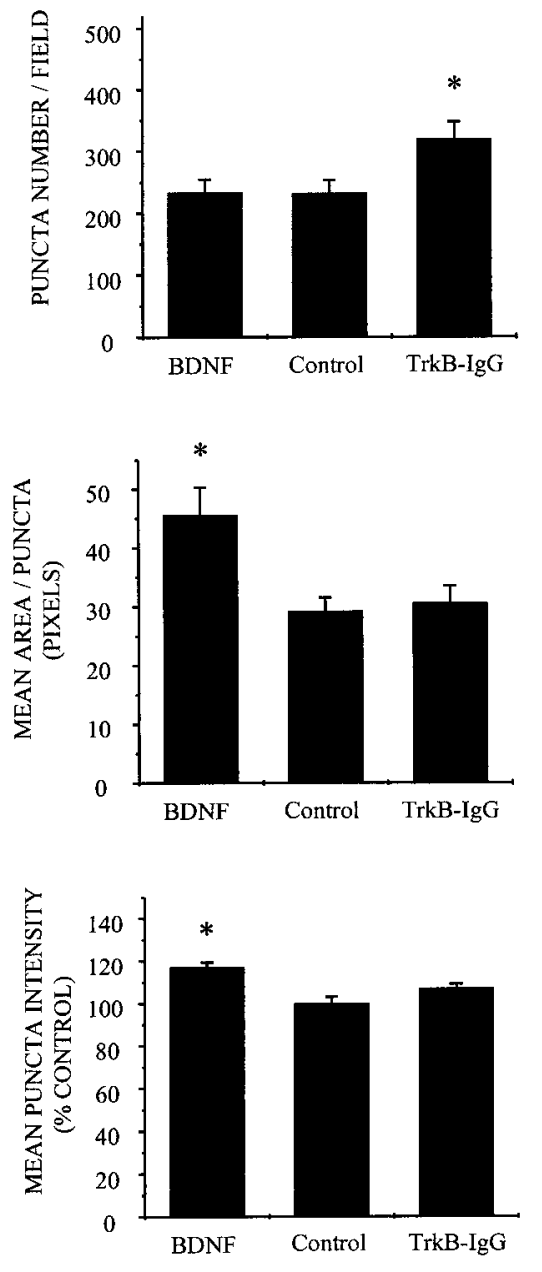

Figure 9. BDNF does not affect synaptogenesis but does enhance GABAergic phenotype. $A, \mathrm{BDNF}$ treatment did not increase synaptic density as quantified by either anti-synapsin (left) or anti-GAD (right) staining; in fact, synaptic density was slightly increased by TrkB-IgG treatment by both measures. ${ }^{*} p<0.03$ indicates significant differences by ANOVA (anti-synapsin) and $p<0.02$ by ANOVA (anti-GAD) between TrkB-IgG and either control or BDNF groups; $n=23$ (antisynapsin) and $n=24$ (anti-GAD) dishes scored in each treatment group. $B$, BDNF treatment did not increase synaptic terminal size significantly in the population as a whole (antisynapsin staining, left) but did increase average GAD-positive terminal size by $\sim 50 \%$. * $p<0.01$ indicates a significant difference by ANOVA between BDNF and either control or TrkB-IgG groups; $n=22,23$, and 21 dishes scored for BDNF, control, and TrkBIgG treatment groups, respectively. $C$, Similarly, BDNF treatment did not affect the intensity of synapsin labeling (left) but did increase the average staining intensity of GAD-positive terminals (right). ${ }^{*} p<0.002$ indicates a significant difference by ANOVA between BDNF and either control or TrkB-IgG groups; $n=22,23$, and 24 dishes scored for BDNF, control, and TrkB-IgG treatment groups, respectively. and the alternative splicing variants, GluR Flip and GluR Flop, between pyramidal cells of the hippocampus and cortex (Boulter et al., 1990; Keinanen et al., 1990; Sommer et al., 1990; Monyer et al., 1991; Pellegrini-Giampietro et al., 1991; Petralia and Wenthold, 1992; Craig et al., 1993; Eshhar et al., 1993; Conti et al., 1994). Such differences in subunit expression may contribute to the apparent regional difference in regulation of quantal amplitude by BDNF in hippocampus versus cortex.

\section{BDNF regulation of inhibition}

We found that inhibitory synaptic transmission was also enhanced by chronic BDNF treatment but that the physiological mechanisms underlying this potentiation were different from those that enhanced excitatory synaptic drive. In this case, BDNF selectively increased the frequency of mIPSCs with no effects on their quantal amplitude or kinetic properties. Such frequency changes could have arisen from changes in probability of transmitter release, numbers of inhibitory synaptic contacts, or both. Our finding that the number of GABAergic terminals was not affected by BDNF but that the size of inhibitory terminals and intensity of GAD immunostaining was increased suggests that BDNF is likely to have enhanced the probability of transmitter release presynaptically.

The $40 \%$ increase in the ratio of neurons that showed detect- able anti-GAD staining we observed after BDNF treatment was similar to previous reports of increases in GABAergic phenotypic differentiation, but not inhibitory neuronal numbers, after treatment with BDNF in vitro and in vivo (Ip et al., 1993; Nawa et al., 1993, 1994; Croll et al., 1994; Marty et al., 1996a,b). Interestingly, BDNF is not synthesized by GABAergic interneurons (Cellerino et al., 1996; Rocamora et al., 1996; Schmidt-Kastner et al., 1996), but rather their source of BDNF is thought to be neighboring glutamatergic neurons (Nawa et al., 1995; Marty et al., 1996a). Such observations continue to support a general role for BDNF in regulating inhibitory synaptic transmission and are consistent with BDNF acting as an activity-dependent, target-derived differentiation factor for GABAergic interneurons. In turn, such regulation of GABAergic transmission by BDNF and activity would be expected to have major ramifications for neural development and function (Hendry and Jones, 1988).

In summary, our experiments have shown that BDNF can have profound effects on the function of neural circuits and that it can do so via regulation of selective aspects of excitatory and inhibitory synaptic function. In combination with activity-dependent production and localized release of neurotrophins (Wetmore et al., 1994; Blochl and Thoenen, 1995, 1996; Goodman et al., 1996; 
Fawcett et al., 1997, 1998; Smith et al., 1997; Wang and Poo, 1997; Moller et al., 1998), such effects of BDNF provide powerful mechanisms of action in their increasingly apparent roles in regulating synaptic development and plasticity.

\section{REFERENCES}

Akaneya Y, Tsumoto T, Hatanaka H (1996) Brain-derived neurotrophic factor blocks long-term depression in rat visual cortex. J Neurophysiol 76:4198-4201.

Akaneya Y, Tsumoto T, Kinoshita S, Hatanaka H (1997) Brain-derived neurotrophic factor enhances long-term potentiation in rat visual cortex. J Neurosci 17:6707-6716.

Barria A, Derkach V, Soderling T (1997a) Identification of the $\mathrm{Ca}^{2+}$ / calmodulin-dependent protein kinase II regulatory phosphorylation site in the alpha-amino-3-hydroxyl-5-methyl-4-isoxazole-propionatetype glutamate receptor. J Biol Chem 272:32727-32730.

Barria A, Muller D, Derkach V, Griffith LC, Soderling TR (1997b) Regulatory phosphorylation of AMPA-type glutamate receptors by CaM-KII during long-term potentiation. Science 276:2042-2045.

Bekkers JM, Stevens CF (1996) Cable properties of cultured hippocampal neurons determined from sucrose-evoked miniature EPSCs. J Neurophysiol 75:1250-1255.

Benke TA, Luthi A, Isaac JT, Collingridge GL (1998) Modulation of AMPA receptor unitary conductance by synaptic activity. Nature 393:793-797.

Blochl A, Thoenen H (1995) Characterization of nerve growth factor (NGF) release from hippocampal neurons: evidence for a constitutive and an unconventional sodium-dependent regulated pathway. Eur J Neurosci 7:1220-1228.

Blochl A, Thoenen H (1996) Localization of cellular storage compartments and sites of constitutive and activity-dependent release of nerve growth factor (NGF) in primary cultures of hippocampal neurons. Mol Cell Neurosci 7:173-190.

Boulanger L, Poo M (1999a) Gating of BDNF-induced synaptic potentiation by cAMP. Science 284:1982-1984.

Boulanger L, Poo MM (1999b) Presynaptic depolarization facilitates neurotrophin-induced synaptic potentiation. Nat Neurosci 2:346-351.

Boulter J, Hollmann M, O'Shea-Greenfield A, Hartley M, Deneris E, Maron C, Heinemann S (1990) Molecular cloning and functional expression of glutamate receptor subunit genes. Science 249:1033-1037.

Carmignoto G, Vicini S (1992) Activity-dependent decrease in NMDA receptor responses during development of the visual cortex. Science 258:1007-1011.

Carmignoto G, Pizzorusso T, Tia S, Vicini S (1997) Brain-derived neurotrophic factor and nerve growth factor potentiate excitatory synaptic transmission in the rat visual cortex. J Physiol (Lond) 498:153-164.

Carroll RC, Lissin DV, von Zastrow M, Nicoll RA, Malenka RC (1999) Rapid redistribution of glutamate receptors contributes to long-term depression in hippocampal cultures. Nat Neurosci 2:454-460.

Cellerino A, Maffei L, Domenici L (1996) The distribution of brainderived neurotrophic factor and its receptor trkB in parvalbumincontaining neurons of the rat visual cortex. Eur $\mathrm{J}$ Neurosci 8:1190-1197.

Clements JD (1996) Transmitter timecourse in the synaptic cleft: its role in central synaptic function. Trends Neurosci 19:163-171.

Conti F, Minelli A, Brecha NC (1994) Cellular localization and laminar distribution of AMPA glutamate receptor subunits mRNAs and proteins in the rat cerebral cortex. J Comp Neurol 350:241-259.

Craig AM, Blackstone CD, Huganir RL, Banker G (1993) The distribution of glutamate receptors in cultured rat hippocampal neurons: postsynaptic clustering of AMPA-selective subunits. Neuron 10:1055-1068.

Croll SD, Wiegand SJ, Anderson KD, Lindsay RM, Nawa H (1994) Regulation of neuropeptides in adult rat forebrain by the neurotrophins BDNF and NGF. Eur J Neurosci 6:1343-1353.

Derkach V, Barria A, Soderling TR (1999) $\mathrm{Ca}^{2+} /$ calmodulin-kinase II enhances channel conductance of alpha-amino-3-hydroxy-5-methyl-4isoxazolepropionate type glutamate receptors. Proc Natl Acad Sci USA 96:3269-3274.

Diamond JS, Jahr CE (1997) Transporters buffer synaptically released glutamate on a submillisecond time scale. J Neurosci 17:4672-4687.

Durand GM, Kovalchuk Y, Konnerth A (1996) Long-term potentiation and functional synapse induction in developing hippocampus. Nature 381:71-75.
Eshhar N, Petralia RS, Winters CA, Niedzielski AS, Wenthold RJ (1993) The segregation and expression of glutamate receptor subunits in cultured hippocampal neurons. Neuroscience 57:943-964.

Fawcett JP, Aloyz R, McLean JH, Pareek S, Miller FD, McPherson PS, Murphy RA (1997) Detection of brain-derived neurotrophic factor in a vesicular fraction of brain synaptosomes. J Biol Chem 272:8837-8840.

Fawcett JP, Bamji SX, Causing CG, Aloyz R, Ase AR, Reader TA, McLean JH, Miller FD (1998) Functional evidence that BDNF is an anterograde neuronal trophic factor in the CNS. J Neurosci 18:2808-2821.

Figurov A, Pozzo-Miller LD, Olafsson P, Wang T, Lu B (1996) Regulation of synaptic responses to high-frequency stimulation and LTP by neurotrophins in the hippocampus. Nature 381:706-709.

Frerking M, Malenka RC, Nicoll RA (1998) Brain-derived neurotrophic factor (BDNF) modulates inhibitory, but not excitatory, transmission in the CA1 region of the hippocampus. J Neurophysiol 80:3383-3386.

Goodman LJ, Valverde J, Lim F, Geschwind MD, Federoff HJ, Geller AI, Hefti F (1996) Regulated release and polarized localization of brain-derived neurotrophic factor in hippocampal neurons. Mol Cell Neurosci 7:222-238.

Gottschalk W, Pozzo-Miller LD, Figurov A, Lu B (1998) Presynaptic modulation of synaptic transmission and plasticity by brain-derived neurotrophic factor in the developing hippocampus. J Neurosci 18:6830-6839.

Hamill OP, Marty A, Neher E, Sakmann B, Sigworth FJ (1981) Improved patch-clamp techniques for high-resolution current recording from cells and cell-free membrane patches. Pflügers Arch 391:85-100.

Hendry SH, Jones EG (1988) Activity-dependent regulation of GABA expression in the visual cortex of adult monkeys. Neuron 1:701-712.

Hestrin S (1992) Developmental regulation of NMDA receptormediated synaptic currents at a central synapse. Nature 357:686-689.

Huber KM, Sawtell NB, Bear MF (1998) Brain-derived neurotrophic factor alters the synaptic modification threshold in visual cortex. Neuropharmacology 37:571-579.

Ip NY, Li Y, Yancopoulos GD, Lindsay RM (1993) Cultured hippocampal neurons show responses to BDNF, NT-3, and NT-4, but not NGF. J Neurosci 13:3394-3405.

Isaac JT, Nicoll RA, Malenka RC (1995) Evidence for silent synapses: implications for the expression of LTP. Neuron 15:427-434.

Kang H, Schuman EM (1995a) Long-lasting neurotrophin-induced enhancement of synaptic transmission in the adult hippocampus. Science 267:1658-1662.

Kang HJ, Schuman EM (1995b) Neurotrophin-induced modulation of synaptic transmission in the adult hippocampus. J Physiol (Paris) 89:11-22.

Keinanen K, Wisden W, Sommer B, Werner P, Herb A, Verdoorn TA, Sakmann B, Seeburg PH (1990) A family of AMPA-selective glutamate receptors. Science 249:556-560.

Kinoshita S, Yasuda H, Taniguchi N, Katoh-Semba R, Hatanaka H, Tsumoto T (1999) Brain-derived neurotrophic factor prevents lowfrequency inputs from inducing long-term depression in the developing visual cortex. J Neurosci 19:2122-2130.

Korte M, Carroll P, Wolf E, Brem G, Thoenen H, Bonhoeffer T (1995) Hippocampal long-term potentiation is impaired in mice lacking brainderived neurotrophic factor. Proc Natl Acad Sci USA 92:8856-8860.

Korte M, Griesbeck O, Gravel C, Carroll P, Staiger V, Thoenen H, Bonhoeffer T (1996a) Virus-mediated gene transfer into hippocampal CA1 region restores long-term potentiation in brain-derived neurotrophic factor mutant mice. Proc Natl Acad Sci USA 93:12547-12552.

Korte M, Staiger V, Griesbeck O, Thoenen H, Bonhoeffer T (1996b) The involvement of brain-derived neurotrophic factor in hippocampal long-term potentiation revealed by gene targeting experiments. J Physiol (Paris) 90:157-164.

Korte M, Kang H, Bonhoeffer T, Schuman E (1998) A role for BDNF in the late-phase of hippocampal long-term potentiation. Neuropharmacology 37:553-559.

Lesser SS, Lo DC (1995) Regulation of voltage-gated ion channels by NGF and ciliary neurotrophic factor in SK-N-SH neuroblastoma cells. J Neurosci 15:253-261.

Lesser SS, Sherwood NT, Lo DC (1997) Neurotrophins differentially regulate voltage-gated ion channels. Mol Cell Neurosci 10:173-183.

Lessmann V, Heumann R (1998) Modulation of unitary glutamatergic synapses by neurotrophin- $4 / 5$ or brain-derived neurotrophic factor in hippocampal microcultures: presynaptic enhancement depends on preestablished paired-pulse facilitation. Neuroscience 86:399-413. 
Lessmann V, Gottmann K, Heumann R (1994) BDNF and NT-4/5 enhance glutamatergic synaptic transmission in cultured hippocampal neurones. NeuroReport 6:21-25.

Levine ES, Dreyfus CF, Black IB, Plummer MR (1995) Brain-derived neurotrophic factor rapidly enhances synaptic transmission in hippocampal neurons via postsynaptic tyrosine kinase receptors. Proc Natl Acad Sci USA 92:8074-8077.

Levine ES, Dreyfus CF, Black IB, Plummer MR (1996) Selective role for trkB neurotrophin receptors in rapid modulation of hippocampal synaptic transmission. Brain Research. Mol Brain Res 38:300-303.

Levine ES, Crozier RA, Black IB, Plummer MR (1998) Brain-derived neurotrophic factor modulates hippocampal synaptic transmission by increasing $N$-methyl-D-aspartic acid receptor activity. Proc Natl Acad Sci USA 95:10235-10239.

Li YX, Xu Y, Ju D, Lester HA, Davidson N, Schuman EM (1998) Expression of a dominant negative TrkB receptor, T1, reveals a requirement for presynaptic signaling in BDNF-induced synaptic potentiation in cultured hippocampal neurons. Proc Natl Acad Sci USA 95:10884-10889.

Liao D, Hessler NA, Malinow R (1995) Activation of postsynaptically silent synapses during pairing-induced LTP in CA1 region of hippocampal slice. Nature 375:400-404.

Lissin DV, Carroll RC, Nicoll RA, Malenka RC, von Zastrow M (1999) Rapid, activation-induced redistribution of ionotropic glutamate receptors in cultured hippocampal neurons. J Neurosci 19:1263-1272.

Lohof AM, Ip NY, Poo MM (1993) Potentiation of developing neuromuscular synapses by the neurotrophins NT-3 and BDNF. Nature 363:350-353.

Mammen AL, Kameyama K, Roche KW, Huganir RL (1997) Phosphorylation of the alpha-amino-3-hydroxy-5-methylisoxazole-4-propionic acid receptor GluR1 subunit by calcium/calmodulin-dependent kinase II. J Biol Chem 272:32528-32533.

Marty S, Onteniente B (1997) The expression pattern of somatostatin and calretinin by postnatal hippocampal interneurons is regulated by activity-dependent and -independent determinants. Neuroscience 80:79-88.

Marty S, Berninger B, Carroll P, Thoenen H (1996a) GABAergic stimulation regulates the phenotype of hippocampal interneurons through the regulation of brain-derived neurotrophic factor. Neuron 16:565-570.

Marty S, Carroll P, Cellerino A, Castren E, Staiger V, Thoenen H, Lindholm D (1996b) Brain-derived neurotrophic factor promotes the differentiation of various hippocampal nonpyramidal neurons, including Cajal-Retzius cells, in organotypic slice cultures. J Neurosci 16:675-687.

McAllister AK, Katz LC, Lo DC (1996) Neurotrophin regulation of cortical dendritic growth requires activity. Neuron 17:1057-1064.

McAllister AK, Katz LC, Lo DC (1997) Opposing roles for endogenous BDNF and NT-3 in regulating cortical dendritic growth. Neuron 18:767-778.

McAllister AK, Katz LC, Lo DC (1999) Neurotrophins and synaptic plasticity. Annu Rev Neurosci 22:295-318.

Mennerick S, Que J, Benz A, Zorumski CF (1995) Passive and synaptic properties of hippocampal neurons grown in microcultures and in mass cultures. J Neurophysiol 73:320-332.

Mennerick S, Shen W, Xu W, Benz A, Tanaka K, Shimamoto K, Isenberg KE, Krause JE, Zorumski CF (1999) Substrate turnover by transporters curtails synaptic glutamate transients. J Neurosci 19:9242-9251.

Mizuno K, Carnahan J, Nawa H (1994) Brain-derived neurotrophic factor promotes differentiation of striatal GABAergic neurons. Dev Biol 165:243-256.

Moller JC, Kruttgen A, Heymach Jr JV, Ghori N, Shooter EM (1998) Subcellular localization of epitope-tagged neurotrophins in neuroendocrine cells. J Neurosci Res 51:463-472.

Monyer H, Seeburg PH, Wisden W (1991) Glutamate-operated channels: developmentally early and mature forms arise by alternative splicing. Neuron 6:799-810.

Narisawa-Saito M, Carnahan J, Araki K, Yamaguchi T, Nawa H (1999a) Brain-derived neurotrophic factor regulates the expression of AMPA receptor proteins in neocortical neurons. Neuroscience 88:1009-1014.

Narisawa-Saito M, Silva AJ, Yamaguchi T, Hayashi T, Yamamoto T, Nawa H (1999b) Growth factor-mediated Fyn signaling regulates alpha-amino-3- hydroxy-5-methyl-4-isoxazolepropionic acid (AMPA) receptor expression in rodent neocortical neurons. Proc Natl Acad Sci USA 96:2461-2466.
Nawa H, Bessho Y, Carnahan J, Nakanishi S, Mizuno K (1993) Regulation of neuropeptide expression in cultured cerebral cortical neurons by brain-derived neurotrophic factor. J Neurochem 60:772-775.

Nawa H, Pelleymounter MA, Carnahan J (1994) Intraventricular administration of BDNF increases neuropeptide expression in newborn rat brain. J Neurosci 14:3751-3765.

Nawa H, Carnahan J, Gall C (1995) BDNF protein measured by a novel enzyme immunoassay in normal brain and after seizure: partial disagreement with mRNA levels. Eur J Neurosci 7:1527-1535.

O’Brien RJ, Kamboj S, Ehlers MD, Rosen KR, Fischbach GD, Huganir RL (1998) Activity-dependent modulation of synaptic AMPA receptor accumulation. Neuron 21:1067-1078.

Pan ZZ, Tong G, Jahr CE (1993) A false transmitter at excitatory synapses. Neuron 11:85-91.

Patterson SL, Abel T, Deuel TA, Martin KC, Rose JC, Kandel ER (1996) Recombinant BDNF rescues deficits in basal synaptic transmission and hippocampal LTP in BDNF knockout mice. Neuron 16:1137-1145.

Pellegrini-Giampietro DE, Bennett MV, Zukin RS (1991) Differential expression of three glutamate receptor genes in developing rat brain: an in situ hybridization study. Proc Natl Acad Sci USA 88:4157-4161.

Petralia RS, Wenthold RJ (1992) Light and electron immunocytochemical localization of AMPA-selective glutamate receptors in the rat brain. J Comp Neurol 318:329-354.

Pothos EN, Davila V, Sulzer D (1998) Presynaptic recording of quanta from midbrain dopamine neurons and modulation of the quantal size. J Neurosci 18:4106-4118.

Reimer RJ, Fon EA, Edwards RH (1998) Vesicular neurotransmitter transport and the presynaptic regulation of quantal size. Curr Opin Neurobiol 8:405-412.

Riddle DR, Katz LC, Lo DC (1997) Focal delivery of neurotrophins into the central nervous system using fluorescent latex microspheres. Biotechniques 23:928-934, 936-937.

Rocamora N, Pascual M, Acsady L, de Lecea L, Freund TF, Soriano E (1996) Expression of NGF and NT3 mRNAs in hippocampal interneurons innervated by the GABAergic septohippocampal pathway. J Neurosci 16:3991-4004.

Rutherford LC, DeWan A, Lauer HM, Turrigiano GG (1997) Brainderived neurotrophic factor mediates the activity-dependent regulation of inhibition in neocortical cultures. J Neurosci 17:4527-4535.

Rutherford LC, Nelson SB, Turrigiano GG (1998) BDNF has opposite effects on the quantal amplitude of pyramidal neuron and interneuron excitatory synapses. Neuron 21:521-530.

Scharfman HE (1997) Hyperexcitability in combined entorhinal/hippocampal slices of adult rat after exposure to brain-derived neurotrophic factor. J Neurophysiol 78:1082-1095.

Scharfman HE, Goodman JH, Sollas AL (1999) Actions of brainderived neurotrophic factor in slices from rats with spontaneous seizures and mossy fiber sprouting in the dentate gyrus. J Neurosci 19:5619-5631.

Schmidt-Kastner R, Wetmore C, Olson L (1996) Comparative study of brain-derived neurotrophic factor messenger RNA and protein at the cellular level suggests multiple roles in hippocampus, striatum and cortex. Neuroscience 74:161-183.

Sermasi E, Tropea D, Domenici L (1999) A new form of synaptic plasticity is transiently expressed in the developing rat visual cortex: a modulatory role for visual experience and brain-derived neurotrophic factor. Neuroscience 91:163-173.

Shelton DL, Sutherland J, Gripp J, Camerato T, Armanini MP, Phillips HS, Carroll K, Spencer SD, Levinson AD (1995) Human trks: molecular cloning, tissue distribution, and expression of extracellular domain immunoadhesins. J Neurosci 15:477-491.

Sherwood NT, Lo DC (1999) Long-term enhancement of central synaptic transmission by chronic brain-derived neurotrophic factor treatment. J Neurosci 19:7025-7036.

Sherwood NT, Lesser SS, Lo DC (1997) Neurotrophin regulation of ionic currents and cell size depends on cell context. Proc Natl Acad Sci USA 94:5917-5922.

Shi SH, Hayashi Y, Petralia RS, Zaman SH, Wenthold RJ, Svoboda K, Malinow R (1999) Rapid spine delivery and redistribution of AMPA receptors after synaptic NMDA receptor activation. Science 284:1811-1816.

Smith MA, Zhang LX, Lyons WE, Mamounas LA (1997) Anterograde transport of endogenous brain-derived neurotrophic factor in hippocampal mossy fibers. NeuroReport 8:1829-1834.

Sommer B, Keinanen K, Verdoorn TA, Wisden W, Burnashev N, Herb 
A, Kohler M, Takagi T, Sakmann B, Seeburg PH (1990) Flip and flop: a cell-specific functional switch in glutamate-operated channels of the CNS. Science 249:1580-1585.

Song DK, Choe B, Bae JH, Park WK, Han IS, Ho WK, Earm YE (1998) Brain-derived neurotrophic factor rapidly potentiates synaptic transmission through NMDA, but suppresses it through non-NMDA receptors in rat hippocampal neuron. Brain Res 799:176-179.

Stoop R, Poo MM (1996) Synaptic modulation by neurotrophic factors: differential and synergistic effects of brain-derived neurotrophic factor and ciliary neurotrophic factor. J Neurosci 16:3256-3264.

Tan SE, Wenthold RJ, Soderling TR (1994) Phosphorylation of AMPAtype glutamate receptors by calcium/calmodulin-dependent protein kinase II and protein kinase $\mathrm{C}$ in cultured hippocampal neurons. J Neurosci 14:1123-1129.

Turrigiano GG (1999) Homeostatic plasticity in neuronal networks: the more things change, the more they stay the same. Trends Neurosci 22:221-227.

Turrigiano GG, Nelson SB (1998) Thinking globally, acting locally: AMPA receptor turnover and synaptic strength. Neuron 21:933-935.

Turrigiano GG, Leslie KR, Desai NS, Rutherford LC, Nelson SB (1998)
Activity-dependent scaling of quantal amplitude in neocortical neurons. Nature 391:892-896.

Ventimiglia R, Mather PE, Jones BE, Lindsay RM (1995) The neurotrophins BDNF, NT-3 and NT-4/5 promote survival and morphological and biochemical differentiation of striatal neurons in vitro. Eur $\mathrm{J}$ Neurosci 7:213-222.

Vicario-Abejon C, Collin C, McKay RD, Segal M (1998) Neurotrophins induce formation of functional excitatory and inhibitory synapses between cultured hippocampal neurons. J Neurosci 18:7256-7271.

Wang T, Xie K, Lu B (1995) Neurotrophins promote maturation of developing neuromuscular synapses. J Neurosci 15:4796-4805.

Wang XH, Poo MM (1997) Potentiation of developing synapses by postsynaptic release of neurotrophin-4. Neuron 19:825-835.

Wetmore C, Olson L, Bean AJ (1994) Regulation of brain-derived neurotrophic factor (BDNF) expression and release from hippocampal neurons is mediated by non-NMDA type glutamate receptors. J Neurosci 14:1688-1700.

Wu G, Malinow R, Cline HT (1996) Maturation of a central glutamatergic synapse. Science 274:972-976. 